\title{
Impact of Construction of AMD Permai Housing on the Socio-Economic Conditions of the Surrounding Community
}

\author{
Akhmad Munaya Rahman ${ }^{1 *}$ Ahmad Ramadhan ${ }^{1}$ Karunia Puji Hastuti ${ }^{1}$ \\ ${ }^{I}$ Geography Education, Faculty of Education and Teaching, University Lambung Mangkurat, Banjarmasin, Indonesia. \\ ${ }^{*}$ Corresponding author.Email: munaya.rahman@ulm.ac.id
}

\begin{abstract}
Development in the housing sector in the North Banjarmasin District, especially the AMD picturesque housing complex, is very rapid. Housing development certainly has various impacts on people's lives, such as socioeconomic conditions. The research was conducted with the aim of analyzing the impact of housing development on the socio-economic conditions of the surrounding community. The research design used qualitative methods. The research informants included the head of the sub-district, village head, community leaders, and the community around the affected housing. Data collection was carried out through interviews. Data analysis used an interactive model, by collecting data from interviews with informants. The data collected was then reduced to see the completeness and clarity of the informants' responses. The results of the reduction are then displayed in the form of descriptions, charts, and a matrix regarding the results of interviews regarding the impact of housing development on the socio-economic conditions of the community. The results showed that AMD Permai housing development was able to improve the socio-economic conditions of the surrounding community. The community gets quality education and health facilities as well as affordable access. Job opportunities are increasingly open so that the income of the community around the housing has increased.
\end{abstract}

Keywords: Housing development, socio-economic conditions, surrounding communities

\section{INTRODUCTION}

Development is a planning process (social plan) carried out by development planning bureaucrats to make welfare a process of increasing welfare for the community [1]. Development is a process of transforming society from one state to another which is closer to the ideal society order, in the transformation process there are two things that need to be considered, namely: sustainability and change, the attraction between the two creates dynamics in community development [2]. Development is a planned process of change which contains updates for a more advanced community life. One of the impacts of this development is the changing socio-economic conditions of the community [3].

Banjarmasin is a city in South Kalimantan Province as well as the largest metropolitan city in South Kalimantan Province. Data from the Central Statistics Agency stated that in 2010 the population of Banjarmasin City was 628,199 people, and an increase in 2018, namely 700,869 people. BPS data shows that the population of Banjarmasin City continues to grow. The impact that can be seen clearly as a result of population growth in Banjarmasin City is development that is physical and visible, such as development in the housing sector [4].

Housing development is an integral part of national development. The government will create and support all forms of business in the housing and settlement sector.
Housing and settlements are a form of shelter that has a very close relationship with the community. Housing and settlements in a location more or less reflect the characteristics of the people who live in these houses and settlements [5].

High population growth has an impact on high housing needs [6]. Banjarmasin city has 5 districts, one of which is North Banjarmasin District. Based on data from the Central Bureau of Statistics for the City of Banjarmasin, from 2013 to 2018 , North Banjarmasin is in the first place with the highest population compared to other sub-districts, namely 145,656 people in 2013 and 164,305 people in 2018[7]. In 2013-2018, the population growth rate was also the highest compared to other sub-districts, namely $2.5 \%$. Data from the Banjarmasin City Housing and Settlement Service in 2018 stated that the number of housing units in North Banjarmasin District was 27,653 units, South Banjarmasin with 25,955 units, Central Banjarmasin with 20,031 units, West Banjarmasin with 11,085 units, and East Banjarmasin with 23,868 units.[8]. Based on data, North Banjarmasin District is the highest number of housing compared to other Districts, with an average growth from 2013 to 2018 of $0.65 \%$ [7].

Data from the Banjarmasin City Housing and Settlement Service stated that in 2018 the average housing area in North Banjarmasin District was 64,982 hectares, with an average number of buildings of 226 units. AMD Permai Housing has an area of 435,417 hectares, with a total of 
2,784 housing units. Based on these data, AMD Permai Housing is the largest housing complex located in North Banjarmasin District, Banjarmasin City[8]. AMD Permai Housing is one of the housing under the auspices of the housing company (Developer) PT Awang Sejahtera Permai whose residential building units are located in two subdistricts, namely Alalak Utara, Alalak Tengah, and Alalak Selatan Villages [9].

AMD housing development has an impact on the socioeconomic conditions of the surrounding community. The public's view of education has changed, now they are more concerned with education, this is evident because the majority of people are high school graduates, some even continue to higher education. The conversion of land from agriculture to housing has an impact on community jobs, many of whom work in housing, men become garbage collectors in housing estates because their salaries are higher than their previous jobs, namely as laborers and farmers. Some housewives who initially did not work, since their housing availability chose to work as domestic helpers or baby sitters, they chose to work to support their economic needs.

\section{METHOD}

The research design used qualitative methods. Qualitative methods are used to examine the conditions of natural objects, where the researcher is the key instrument. Key informants in this study were 8 people, namely: Secretary of North Banjarmasin District 1 person, Head of North Alalak Village 1 person, and 1 person of Central Alalak Village, and 5 community leaders. Meanwhile, supporting informants are 12 people who work and are affected in AMD Permai Housing. The data collection technique is done by triangulation (merging). Data analysis used an interactive model, with the technique of collecting interview data with informants. The data collected was then reduced to see the completeness and clarity of the informants' responses. The results of the reduction are then displayed in the form of descriptions, charts, and an interview matrix regarding the impact of housing development on the socio-economic conditions of the community.

\section{RESULTS AND DISCUSSION \\ 3.1 Impact on Education}

\subsubsection{Access to Education}

Access roads to educational facilities after the construction of AMD Housing became easier and more affordable because the roads were paved. The government pays more attention to road conditions. People no longer need to take detours to get to school. With better road access, students can go to school comfortably and more safely, the easier access to educational facilities will support the better educational facilities and infrastructure [10].

\subsubsection{Education Ouality and Governance}

The quality and governance of education around AMD Housing is getting better, this cannot be separated from the role of the government and AMD Housing Depelover.
Educational facilities have also increased, such as kindergarten, elementary and junior high schools. School facilities were built to meet the growing needs of the community, especially since new student admissions are now using a zoning system. The better the quality and governance of education, the better the quality of students, that way, the levels after that, both at the university level or the world of work will be easier [11].

\subsubsection{Community Education Level}

The education level of the community prior to the construction of the AMD Housing was still low, on average SD and SMP graduates. Now the education level of the people living around the AMD Housing has paid attention to the importance of education. Most of them have attended high school (SMA). In 2019, the number of high school / equivalent graduates in Alalak Utara Village was 4368 people or $20.78 \%$, and in Alalak Tengah Village there were 1,628 people or $16.96 \%$. This figure is the highest compared to graduates from other schools such as SD / equivalent, SMP / equivalent, and universities. They have an awareness of the importance of education and emulate residents of AMD Housing who are considered higher educated so they are interested in sending their children to a higher level of education so that it is easier to find work. Education and job factors can lead to community participation in development. Broad knowledge and experience as well as sufficient time outside of work can lead to one's desire to participate in development activities [12].

\subsubsection{Illiterate Society}

The number of illiterate people in Alalak Utara and Alalak Tengah Villages in 2014-2018 has decreased. The decrease in illiteracy rate is due to government programs, especially the Education Office to organize special schools for people who cannot read and write. Government programs are divided into two, namely basic literacy education program services and advanced literacy education. Basic literacy education aims as an educational service for people aged 15 years and over who are illiterate in Latin, as regulated in Permendikbud Number 86 of 2014. Further literacy education is an educational service that organizes learning for people who have finished basic literacy education in order to develop competencies for society after basic literacy education [13].

\subsubsection{Average Length of Looking for a Job After Graduation from School}

The average length of time to look for work in the community around AMD Housing depends on the type of work and their needs. People who graduated from SD and SMP work in a wood factory because they follow their parents' work as a wood worker and the location of the wood factory is close to where they live. After graduating from school, people who want to work in a wood factory don't need to wait for a job call, they go straight to work. People who graduate from high school choose to work in companies, shops, supermarkets, restaurants and so on, usually waiting for work calls for 1-3 months. 
The longer people do not get a job will have an impact on increasing the number of unemployed. Unemployment will cause new problems in the social and economic environment of society, such as having an impact on GDP, decreasing people's purchasing power, decreasing income per capita, increasing crime rates, spreading slum areas, social inequality and so on [14].

\subsection{Impact on Health Facilities}

\subsubsection{Health Care Access}

Before the construction of the AMD Housing, the road access to health facilities such as the Puskesmas was still rocky and during the rainy season the roads were muddy. After the construction of the AMD Housing, access to health facilities became easier and more affordable because the roads were wide and paved. After the construction of the AMD Housing, access to health facilities does not need to be detoured again because there are many shortcuts. The easier access to health facilities will have an impact on public health, a healthy community will support their productivity and social life [15].

\subsubsection{Quality of health services}

After the construction of AMD Housing, the community's need for health facilities is getting higher. More and more health facilities. In 2019, Alalak Utara Village has 1 hospital, 3 clinics, 9 pharmacies, 11 posyandu, and 2 practicing doctors. Meanwhile, in Kelurahan Alalak Tengah there are 1 Puskesmas, 2 clinics, 3 pharmacies, 9 Posyandu, and 1 Practicing Doctor. The quality of health services is getting better. AMD Housing Development has resulted in the development of the surrounding area so that the Government is increasingly paying attention to Puskesmas such as completing its facilities and infrastructure. The better the quality of health services results in a feeling of satisfaction for each patient according to the average satisfaction level of the population which is the main target of health institutions [15].

\subsubsection{Public health}

Most of the communities around the AMD Housing are already concerned about their health, this is inseparable from the socialization from the Puskesmas about public health, besides that, every week there are often morning exercises at AMD Housing. The level of health directly affects the increase in per capita income and has an influence on the level of education [16].

\subsection{Impact on Social Interaction}

\subsubsection{Interaction and Public Relations}

Community interaction after the construction of the AMD Housing is still good. Greetings and mutual cooperation between communities still exist, both fellow communities around the AMD Housing, the surrounding community with residents of AMD Housing, and fellow residents of AMD housing, for example such as mutual cooperation to build bridges, clean up rubbish, weddings, even in harmony with his death in the community. there is. Even so, a small part of the community has started to be individualistic, both residents of housing and communities around AMD Housing.

\subsubsection{Attitudes and Perceptions of the Community}

Attitude is a thought or a person's tendency to recognize certain aspects of the environment, while society's perception is an assessment of others. The community around the AMD housing estate considers residents of AMD perumhan to still have mutual cooperation and their greeting is still there, but some residents of housing are considered more closed and individualistic.

\subsection{Impact on Job Opportunities}

\subsubsection{Job Information}

The community around the AMD Housing often gets job information at AMD Housing. Job information is usually obtained from friends who are already working in AMD Housing, local RTs, neighbors, directly ordered by residential residents, or even look directly at AMD Housing. Residents of AMD Housing usually prioritize the surrounding community because they don't need to stay overnight. Ease of obtaining job information will have a positive impact on job seekers. With a lot of job information that is spread, it makes it easier for job seekers to suit their desires and skills [17].

\subsubsection{Public Interest}

The community around the AMD Housing is interested in working in AMD Housing because the salary is quite high. Some people immediately accept the jobs offered by homeowners and some consider the type of work that corresponds to the salary.

The work interest of the community around the AMD Housing is of interest preventive or also known as biological interest, namely interests that revolve around food and freedom of activity. Supporting factors for the work interest of the surrounding community who work in AMD Housing include working conditions (pleasant atmosphere at work), support systems (access, transportation facilities, and work equipment), and personal work (morale, workers' views of their work, and attitudes towards their work) [18].

\subsubsection{Work experience}

Not all of the communities around AMD Housing who work in AMD Housing have work experience. People who work as household assistants, baby sitters, and garbage collectors generally do not have work experience, while people who work as house builders already have previous work experience.

Work experience will strengthen the ability to perform an action (skills). Individuals who often get the experience of doing their jobs well and will be very skilled and of course will be more professional than other individuals who have never done these actions[19]. 


\subsection{Impact on Income}

\subsubsection{Community Income Before Housing Built}

Before the construction of AMD housing, most people only worked in wood factories, did business, worked as motorcycle taxi drivers, and so on. With an uncertain income, most people admit that this income is not sufficient to meet their daily needs. The income of the community before the construction of AMD Housing was classified as low. The average income of the community before the construction of AMD housing was $<1,500,000$ / month [7].

\subsubsection{Community Income After Housing Built}

After the construction of AMD Housing, the income of the surrounding community has increased. For people who work in AMD Housing, their monthly income is sufficient to meet their daily needs, even some can be saved. The income of the people who work in AMD Housing and the people who sell around AMD is classified as moderate to very high, the average income of the people who work in AMD Housing is $>1,500,000 /$ month [7].

\section{CONCLUSION}

The conclusion is that AMD Housing has an impact on the socio-economic conditions of the surrounding community. In the field of education, AMD housing development has an impact on road access, the quality and governance of education, community education, and illiterate communities, however, AMD housing development does not have an impact on the length of time people seek work. In the health sector, AMD housing development has an impact on road access, facilities and quality of health services, number of health facilities, and public health. After the construction of AMD housing, social interactions such as interaction and community relations are still good, and the attitudes and perceptions of the surrounding community towards housing residents are still good. After the construction of AMD housing, job opportunities for the surrounding community have increased and information is easy to obtain,

\section{REFERENCES}

[1] T. Kartono and H. Nurcholis, "Rural and Urban Community Development," Jakarta Univ. Open, 2015.

[2] S. Syaribulan and M. Nawir, "Showfarm Agro Development," Equilib. J. Educator., vol. 3, no. 2, 2015.

[3] E. Fitriani, "The Impact of Housing Development on the Social and Economic Life of Local Communities: A Case Study of Community Socio-Economic Life in Ligar Mekar Village, Cibeunying Village, Bandung Regency." Indonesian University of Education, 2016.

[4] A. Jauhari and S. Ritohardoyo, "The impact of housing development on changes in land use and socio-economic conditions of land sellers in Mlati District," J. Bumi Indones., vol. 2, no. 2, pp. 192
201, 2013.

[5] I. Santoso, Environmental health of urban settlements. Gosyen Publishing, 2015.

[6] A. SUSANTI and NUR Amilia, "The Impact of Housing Development on Increasing Community Economy in Sukodono District, Sidoarjo Regency," Swara Bhumi, vol. 2, no. 1, pp. 34-39, 2013.

[7] BP Statistics, "Banjarmasin City in Numbers," Banjarmasin Agency Pus. Stat. Banjarmasin City, 2019.

[8] Housing and Settlement Areas Service, Data on Housing Complexes in North Banjarmasin District in 2019. Banjarmasin City, 2019.

[9] N. Huda, "Analysis of the Influence of Product Quality and Service Quality on Customer Satisfaction (Studies in the Amd Permai Housing Complex, Banjarmasin)," JWM (Management Insights Journal), vol. 2, no. 1, pp. 43-56, 2016.

[10] L. Hakim, "Equitable access to education for the people is in accordance with the mandate of Law Number 20 of 2003 concerning the National Education System," EduTech J. Science Educators. And Science Sos., vol. 2, no. 1, 2016.

[11] IDP Subamia, "Analysis of the management needs of junior high school science laboratory governance in Buleleng Regency," JPI (Journal of Educators. Indones., vol. 3, no. 2, 2015.

[12] KA Udin, "The relationship between the level of education and the type of work with community participation in development in Jetis Village, Jaten District, Karanganyar Regency in 2009/2010." UNS (Sebelas Maret University), 2010.

[13] Permendikbud, Regulation of the Minister of Education and Culture of the Republic of Indonesia. Indonesia, 2015.

[14] KD Indarto and S. Rahayu, "The Impact of Housing Development on Environmental, Social and Economic Conditions of the Surrounding Community in Sambiroto Village, Tembalang District," Tech. PWK (Urban Wil. Planning), vol. 4, no. 3, pp. 428-439, 2015.

[15] IPA Finkayana and P. Arya, "Analysis of Economic Growth and Indicators of Impictional HDI on the Number of Poor People in Bali Province in 2004 2013," J. Econ. Pembang. Univ. Udayana, vol. 5, no. 7, 2016.

[16] R. Syamsurizal, AB Setiyawan, B. Pudjianto, and RY Adi, "Optimizing the Use of Parking Spaces at the Faculty of Public Health, Diponegoro University," J. TECH WORKS. CIVIL, vol. 2, no. 2, pp. 391-396, 2013.

[17] NG Mankiw, "Introduction to Macroeconomics," Ed. Third. Jakarta Salemba Empat, 2006.

[18] R. Masfufah, "Islamic guidance and counseling 
with rational emotive behavior therapy in fostering work interest in adolescents: a case study: an adolescent graduate from a boarding school who has not worked in Sekaran Village, Sekaran District, Lamongan Regency," 2012.

[19] JO Kapahang, C. Kojo, and Y. Uhing, "Education,
Work Experience and Competence Influence Employee Performance at PT. PLN (Persero) Suluttenggo Region, "J. EMBA J. Ris. Econ. Management, Business and Accounts., vol. 2, no. 4, 2014. 